\title{
Severe Acute Respiratory Syndrome-coronavirus 2 Interstitial Bilateral Pneumonia: A Case Report and Review of Literature
}

\author{
Danilo Coco $^{1 *}$, Silvana Leanza ${ }^{2}$ \\ ${ }^{1}$ Department of General Surgery, Ospedali Riuniti Marche Nord, Pesaro, Italy; ${ }^{2}$ Department of General Surgery, Carlo Urbani \\ Hospital, Jesi, Ancona, Italy
}

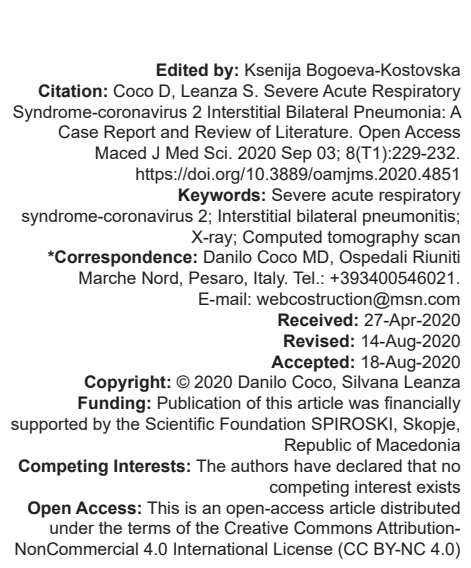

\section{Introduction}

In December 2019, many pneumonia cases were reported in China, Wuhan. The source has shown Huanan Seafood Market as the origin discovering an unexplained pneumonia on December 12, 2019 [1]. On January 22, 2020, novel coronavirus (CoV) has been declared to be originated from wild bats as part of beta-COV who cause severe acute respiratory syndrome-associated COV (SARS-CoV). COVs are zoonotic pathogens that are present in humans and various animals with a wide range of clinical features from asymptomatic course to requirement of hospitalization in the intensive care unit, causing infections in respiratory, gastrointestinal, hepatic, and neurologic systems. All CoVs are pleomorphic RNA viruses characteristically crown shape with 80-160 nM in size and 27-32 kb positive polarity [2], [3], [4], [5]. The disease caused by SARS-CoV-2 is called COV disease (COVID)-19 which has since spread worldwide with major number of patients in China, Italy, Spain, France, and the USA. On March 11, 2020, the WHO declared the outbreak of SARS-CoV-2 a pandemic. Morbidity and mortality of the disease cannot yet estimate but have already seen that lethality appears to be particularly higher in older patients. In a cohort study of 41 hospitalized patients, fever, dry cough, myalgia, and fatigue symptoms were reported in most patients, and less often, symptoms of expectoration, headache, hemoptysis, and diarrhea were also observed [6]. Comorbidities such as underlying hypertension, diabetes mellitus, and cardiovascular disease, and autoimmune diseases were found in about half of these patients. Dyspnea, acute respiratory distress syndrome, and cardiovascular complications accompanied by abnormal thorax computed tomography (CT) compatible with pneumonia mean 8 days after the admission. X-rays or thorax CT images of the patients revealed bilateral multilobar ground-glass opacities (GGOs), with peripheral posterior distribution [7], [8].

The aim of this article is to present a characteristic clinical picture as case report as SARS-COV-2 pneumonia and to provide an overview of the existing literature.

\section{Case report}

A 60-year-old man with a medical history of prostatectomy for cancer, osseous metastases, 
and hormone therapy, presented to the emergency department in mid-March after fever, cough, ageusia, and anosmia at home for 20 days. He referred myalgias and cough at the beginning followed by fevers and said that his symptoms persisted despite the medication with paracetamol and antibiotics. The patient stated that he had shortness of breath in the past 3 days. $\mathrm{He}$ had had no recent travel outside of the state or internationally. On admission, the patient was afebrile with a mild non-productive cough. He had limitation in exercise tolerance during this acute illness. Admission vital signs were heart rate 80 beats/min, blood pressure $150 / 90 \mathrm{mmHg}$, respiratory rate 18 , pulse oximetry $99 \%$ on air, and temperature $36.5^{\circ} \mathrm{C}$. The results of routine laboratory parameters are shown: Leukocytes $10.78 \times 10^{3} / \mathrm{mmc}$, lymphocytes $17.6 \%$, D-DIMERO $5.246 \mathrm{ng} / \mathrm{ml}$ fibrinogen equivalent units, Polymerase Chain Reaction (PCR) $1.10 \mathrm{mg} / \mathrm{dl}$, and pro-calcitonin $0.03 \mathrm{ng} / \mathrm{ml}$. Arterial blood gases (ABGs): $\mathrm{pH} 7,450$, $\mathrm{PCO}_{2} 35.0 \mathrm{mmHg}, \mathrm{PO}_{2} 68.0 \mathrm{mmHg}, \mathrm{PO}_{2} / \mathrm{FiO}_{2}(\mathrm{P} / \mathrm{F}$ ratio) $324.0 \mathrm{mmHg}$. PCR testing for other respiratory viruses, Mycoplasma pneumoniae and Chlamydia pneumoniae, on the throat swab was negative. Nose and throat samples for SARS-CoV-2 PCR were obtained that returned positive. Examination of the lungs reveals murmur reduced and reduce vesicular murmur and tactile vocal fremitus bilaterally. He had also bilateral scleral injection. After arrival, the patient was placed on maximum isolation precautions (negative pressure room, with anyone entering the room required to wear an N95 respirator, face shield, disposable gown, and gloves). A CT chest showed bilaterally multiple patchy GGOs and crazy paving is seen. Some of the opacities are round and some geographic shaped. Partially, the lesions are sharply demarcated against the surrounding healthy lung. The left lower lobe and the periphery of the lungs are predominantly involved (Figure 1a-i). He subsequently worsened because of his $\mathrm{SO}_{2}$ became $85 \%$ despite $12 / / / \mathrm{min}$ of oxygen and his $\mathrm{P} / \mathrm{F}$ ratio was inferior to 200 in a new ABG. Hence, he was admitted in an intensive care unit for mild respiratory failure. He was treated with oxygen therapy using continuous positive airway pressure, adjusted following continuous $A B G$. We associated antibiotics such as azithromycin $500 \mathrm{mg}$ a day, hydrossicloroquine $400 \mathrm{mg}$ day for the first $48 \mathrm{~h}$, and then $200 \mathrm{mg}$ for other 10 days and enoxaparin adjusted following patient weight. Darunavir/cobicistat $800 / 150 \mathrm{mg}$ a day was avoided because 20 days of symptoms onset and tocilizumab was not necessary because the patients improved. He was discharged 15 days after.

\section{Discussion}

Novel CoV has been declared to be originated from wild bats as part of beta-COV who

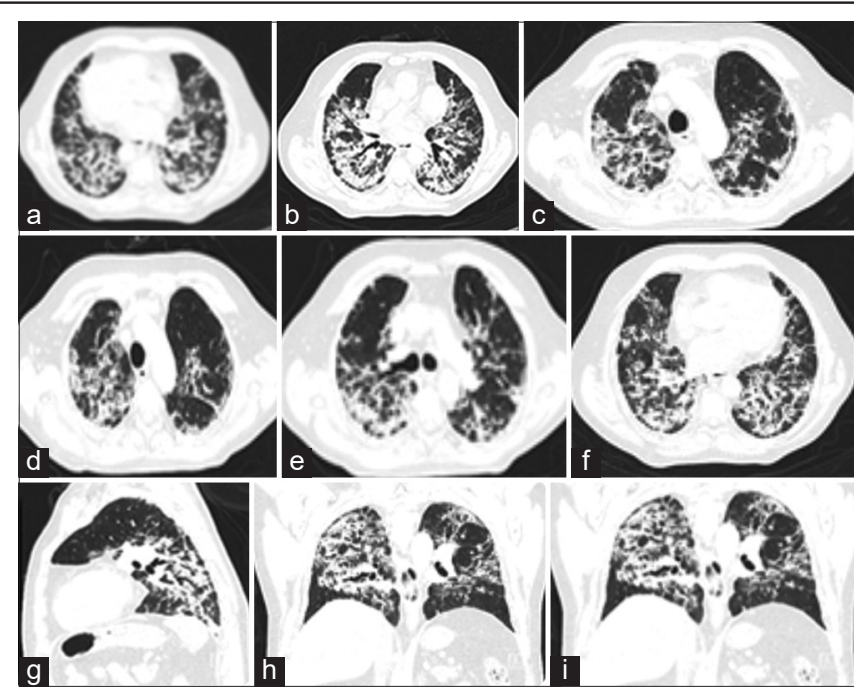

Figure 1: (a-i) Bilaterally multiple patchy ground-glass opacities and crazy paving are seen. Some of the opacities are round and some geographic shaped. Partially, the lesions are sharply demarcated against the surrounding healthy lung. The left lower lobe and the periphery of the lungs are predominantly involved Images

cause SARS-associated COV (SARS-CoV). COVs are zoonotic pathogens that are present in humans and various animals with a wide range of clinical features from asymptomatic course to requirement of hospitalization in the intensive care unit, causing infections in respiratory, gastrointestinal, hepatic, and neurologic systems. Coronaviridae was discovered in the 1960s. The name COV originates from the Latin word corona, meaning "crown" or "halo," due to its characteristic appearance under two-dimensional transmission electron microscopy. COVs have clubshaped spike peplomers covering their surfaces [9] (Figure $2 \mathrm{a}$ and $\mathrm{b}$ ). SARS-CoV, Middle East respiratory syndrome (MERS)-CoV, and SARS-CoV-2 belong to the Coronaviridae family. This family of viruses contains a relatively large single-stranded, positive-sense RNA genome of around $27-32 \mathrm{~kb}$. The most important potential therapeutic target is the spike (S) glycoprotein, which is responsible for the binding of the virus to the host cells. It has been reported that the binding of the viral $S$ protein to angiotensin-converting enzyme (ACE)2 receptors. Increased ACE activity consequently results in the elevated levels of angiotensin II. Once angiotensin II binds to its receptor, AGTR1A, pulmonary vascular permeability is increased [10], [11], [12]. As of April 06, 2020, a total of 1,285,257 cases of COVID-19 occurring in at least 170 countries and territories were reported, with approximately $5.4 \%$ of fatality rate

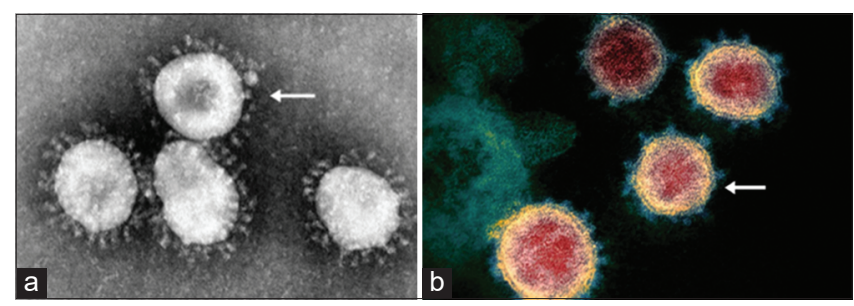

Figure 2: ( $a$ and b) Electron microscopy image of SARS-CoV-2 
$(70,344 / 1,285,257)$ [13]. In a study of 1099 patients in China with confirmed COVID-19, the most commonly reported symptom was fever $(43.8 \%$ on initial admission and $88.7 \%$ during hospitalization) followed by cough $(67.8 \%)$ [14], [15]. Atypical chest and back pain has also been reported as presenting symptoms. Chest CT is more efficient in detecting pneumonia at the early stages of COVID-19. The most common patterns of COVID-19 on chest CT scans include multiple GGO (56.4\%), and bilateral patchy shadowing $(51.8 \%)$, and the other patterns consist of local patchy shadowing $(28.1 \%)$ and interstitial abnormalities (4.4\%) [6], [16], [17]. Today, there is no vaccine or effective treatment to prevent COVID-19 infection. Early diagnosis, reporting, isolation, and basic measures such as hand washing, using disinfectant solutions, avoiding contact with patients, and supportive treatments are the most helpful. There are publications demonstrating that remdesivir has a strong antiviral activity in epithelial cell cultures against SARS-CoV, MERS-CoV, and related zoonotic bat CoV [18], [19]. As part of MERS cure, a randomized control trial (MIRACLE Trial 2016) from South Korea determines that the combination of lopinavir/ritonavir (anti-HIV drugs), pegylated interferon, and ribavirin provided a successful viral clearance [16]. Chloroquine, typically used in the context of malarial or autoimmune disease, has also shown promising results [20], [21]. Tocilizumab is a humanized monoclonal antibody against interleukin-6 receptor (Ab), commonly used as an immunosuppressive in the treatment of rheumatoid arthritis and systemic juvenile idiopathic arthritis seems to be successful [22], [23]. The duration between onset of symptoms and isolation is about 6 days, and it is expected that each 1 day reduction in this period will decrease the size of peak population by $72-84 \%$ and cumulative infected cases and deaths by $68-80 \%$. It is estimated that with the effects of integrated interventions such as promoting the use of face masks and reduced traveling, each $10 \%$ reduction in transmission rate, the size of peak population will decrease by $20-47 \%$, and cumulative infected cases and deaths will decrease by $23-49 \%$ [24].

\section{Conclusions}

SARS-CoV-2 is the COV responsible for the COVID-19 pandemic of 2020. The mean incubation time is 5.1 days (95\% confidence interval [Cl]: $4.5-5.8$ days), with $97.5 \%$ of those who develop symptoms doing so within 11.5 days (95\% Cl: 8.2-15.6 days). Symptoms may vary from mild to severe. Those most affected by COVID-19 are those of advanced age and those with pre-existing chronic medical conditions. Mortality rates are currently unknown: From $0.25 \%$ to $10 \%$. Treatment options are limited. Supportive care is the best choice. Ongoing studies are evaluating the efficacy of remdesivir, chloroquine, hydroxychloroquine, tocilizumab, lopinavir, and ritonavir. At present, no vaccine is available but there are progresses to developing a vaccine over the coming year.

\section{References}

1. Hamer OW, Salzberger B, Gebauer J, Stroszczynski C Pfeifer M. CT morphology of COVID-19: Case report and review of literature. Rofo. 2020;192(5):386-92. https://doi. org/10.1055/a-1142-4094

PMid:32215898

2. Sahin AR, Erdogan A, Agaoglu PM, Dineri Y, Cakirci AY, Senel ME, et al. 2019 Novel coronavirus (COVID-19) outbreak: A review of the current literature. EJMO. 2020;4(1):1-7. https:// doi.org/10.14744/ejmo.2020.12220

3. Woo PC, Huang Y, Lau SK, Yuen KY. Coronavirus genomics and bioinformatics analysis. Viruses. 2010;2(8):1804-20. https:// doi.org/10.3390/v2081803

PMid:21994708

4. Drexler JF, Gloza-Rausch F, Glende J, Corman VM, Muth $D$, Goettsche M, et al. Genomic characterization of severe acute respiratory syndrome-related coronavirus in European bats and classification of coronaviruses based on partial RNA-dependent RNA polymerase gene sequences. J Virol. 2010;84(21):11336-49. https://doi.org/10.1128/jvi.00650-10 PMid:20686038

5. Yin Y, Wunderink RG. MERS, SARS and other coronaviruses as causes of pneumonia. Respirology. 2018;23(2):130-7. https:// doi.org/10.1111/resp.13196

PMid:29052924

6. Huang C, Wang Y, Li X, Ren L, Zhao J, Hu Y, et al. Clinical features of patients infected with 2019 novel coronavirus in Wuhan, China. Lancet. 2020;395(10223):497-506. https://doi. org/10.1016/s0140-6736(20)30183-5

\section{PMid:31986264}

7. Wang C, Horby PW, Harden FG, Gao GF. A novel coronavirus outbreak of global health concern. Lancet. 2020;95(10223):470-3. https://doi.org/10.1016/s0140-6736(20)30185-9

PMid:31986257

8. Salehi S, Abedi A, Balakrishnan S, Gholamrezanezhad A Coronavirus disease 2019 (COVID-19): A systematic review of imaging findings in 919 patients. AJR Am J Roentgenol. 2020;215(1):83-93. https://doi.org/10.2214/ajr.20.23034 PMid:32174129

9. Goldsmith C, Tatti K, Ksiazek T, Rollin PE, Comer JA, Lee WW, et al. Ultrastructural characterization of SARS coronavirus. Emerg Infect Dis. 2004;10(2):320-6. https://doi.org/10.3201/ eid1002.030913

PMid:15030705

10. Pyrc K, Dijkman R, Deng L, Jebbink MF, Ross HA, Berkhout B, et al. Mosaic structure of human Coronavirus NL63, one thousand years of evolution. J Mol Biol. 2006;364(5):964-73. https://doi.org/10.1016/j.jmb.2006.09.074 PMid:17054987

11. Hoffmann M, Kleine-Weber $\mathrm{H}$, Schroeder S, Krüger N, Herrler T, Erichsen S, et al. SARS-CoV-2 cell entry depends on ACE2 and TMPRSS2 and is blocked by a clinically proven protease inhibitor. Cell. 2020;181(2):271-80.e8. https://doi.org/10.1016/j. cell.2020.02.052 


\section{PMid:32142651}

12. Kuba K, Imai Y, Rao S, Gao H, Guo F, Guan B, et al. A crucial role of angiotensin converting enzyme 2 (ACE2) in SARS coronavirus-induced lung injury. Nat Med. 2005;11(8):875-9. https://doi.org/10.1038/nm1267

PMid:16007097

13. Tu YF, Chien CS, Yarmishyn AA, Lin YY, Luo YH, Lin YT, et al. A review of SARS-CoV-2 and the ongoing clinical trials. Int J Mol Sci. 2020;21(7):2657. https://doi.org/10.3390/ijms21072657 PMid:32290293

14. Guan WJ, Ni Z, Hu Y, Liang WH, Ou CQ, He JX, et al. Clinical Characteristics of Coronavirus Disease 2019 in China. N Engl J Med. 2020;382:1708-20.

15. Yoon SH, Lee YH, Kim JY, Lee YK, Ko H, Kim KH, et al. Chest radiographic and $\mathrm{CT}$ findings of the 2019 novel Coronavirus disease (COVID-19): Analysis of nine patients treated in Korea. Korean J Radiol. 2020;21(4):494-500. https://doi.org/10.3348/ kjr.2020.0132 PMid:32100485

16. Chen N, Zhou M, Dong X, Qu J, Gong F, Han $\mathrm{Y}$, et al Epidemiological and clinical characteristics of 99 cases of 2019 novel coronavirus pneumonia in Wuhan, China: A descriptive study. Lancet. 2020;395(10223):507-13. https://doi.org/10.1016/ s0140-6736(20)30211-7

PMid:32007143

17. Wang D, Hu B, Hu C, Zhu F, Liu X, Zhang J, et al. Clinical characteristics of 138 hospitalized patients with 2019 novel coronavirus-infected pneumonia in Wuhan, China. JAMA. 2020;323(11):1061-9. https://doi.org/10.1001/jama.2020.1585 PMid:32031570

18. Cockrell AS, Yount BL, Scobey T, Jensen K, Douglas M, Beall A, et al. A mouse model for MERS coronavirus-induced acute respiratory distress syndrome. Nat Microbiol. 2016;2(2):16226. https://doi.org/10.1038/nmicrobiol.2016.226

PMid:27892925

19. Brown AJ, Won JJ, Graham RL, Dinnon $\mathrm{KH} 3^{\text {rd }}$, Sims AC Feng JY, et al. Broad spectrum antiviral remdesivir inhibits human endemic and zoonotic deltacoronaviruses with a highly divergent RNA dependent RNA polymerase. Antiviral Res. 2019;169:104541. https://doi.org/10.1016/j. antiviral.2019.104541

PMid:31233808

20. Wang M, Cao R, Zhang L, Yang X, Liu J, Xu M, et al. Remdesivir and chloroquine effectively inhibit the recently emerged novel coronavirus (2019-nCoV) in vitro. Cell Res. 2020;30(3):269-71. https://doi.org/10.1038/s41422-020-0282-0

PMid:32020029

21. Gao J, Tian Z, Yang X. Breakthrough: Chloroquine phosphate has shown apparent efficacy in treatment of COVID-19 associated pneumonia in clinical studies. Biosci Trends. 2020;14(1):72-3. https://doi.org/10.5582/bst.2020.01047 PMid:32074550

22. Martinez M. Compounds with therapeutic potential against nove respiratory 2019 coronavirus. Antimicrob Agents Chemother. 2020;1:1-18. https://doi.org/10.1128/aac.00399-20

23. Mehta $P$, McAuley $D$, Brown $M$, Sanchez $E$, Tattersall $R$, Manson J. COVID-19: Consider cytokine storm syndromes and immunosuppression. Lancet. 2020;395(10229):1033-4. https:// doi.org/10.1016/s0140-6736(20)30628-0 PMid:32192578

24. Shen M, Peng Z, Xiao Y, Zhang L. Modelling the Epidemic Trend of the 2019 Novel Coronavirus Outbreak in China. United States: BioRxiv; 2020. https://doi.org/10.1101/2020.01.23.916726 